\title{
Teacher Perceptions toward Professional Learning Community on the Development of Thai Students'21st Century Skills
}

\author{
Wittaya Worapun (Corresponding author) \\ Faculty of Education, Mahasarakham University, Thailand \\ E-mail: Wittaya.wo@msu.ac.th
}

Sinthawa Khamdit

Faculty of Education, Mahasarakham University, Thailand

E-mail: sinthawa.kha@gmail.com

\author{
Pinsuda Siridhrungsri \\ College of Education Science, Dhurakij Pundit University, Thailand \\ E-mail: ppinsuda@gmail.com
}

Received: January 20, 2022 Accepted: February 21, 2022 Published: March 4, 2022

doi:10.5296/jei.v8i1.19485 URL: https://doi.org/10.5296/jei.v8i1.19485

\begin{abstract}
The $21^{\text {st }}$ century skills are important matters in education management in the upcoming era, and they need cooperation among stakeholders of an educational context to be developed. The purpose of the study is to study teacher perceptions toward professional learning community (PLC) in developing 21st century skills of students in Thailand. The samples were 1154 teachers from 376 schools in 17 provinces selected by a purposive sampling method in Thailand. The instruments were a professional learning community activity among teaching staff in the school and a questionnaire for teachers' perception of the method. The data were analyzed using percentages, mean scores, and standard deviation. The results of the study indicate that the perception of teachers on students' 21 st century skills after the PLC was at a high level $(\bar{x}=4.30)$ and higher than before the PLC which was at an average level $(\bar{x}=3.15)$. The results of the study could be summarized to indicate the positive perception of
\end{abstract}


teachers in using the professional learning community as a school managerial method in developing skills and morality of the 21 st century. It could also be concluded that collaboration and idea-sharing among teaching staff and administrators were the keys to success. Therefore, the results of the study could be implicated in school management that aims to develop students' 21 st century skills.

Keywords: Teacher perception, Professional learning community, 21st century skills

\section{Introduction}

The $21^{\text {st }}$ century opens a challenging era for learners to be competitive after they finish their path of education. Knowledge learned in class might not be sufficient to contribute to good life quality. The advance of communicative technology makes information being transferred unlimitedly. The disruptive innovations also change the work market at a significant level (Whorton et al., 2017). Skills that are needed in the previous eras might not be demanded in the future as they are replaced by more cost-effective and untiring technology. In addition, the widened space of communication enables people from different cultures to exchange information. Cross-cultural communicative skills are also needed to avoid misunderstandings in communication. As it seems that new skills are needed in the 21 st century, learners also need an instructional method that contributes to adaptive and meaningful lives (Klafehn, 2017). According to Dede (2009), such skills are digital literacy, inventive thinking, effective communication, and high productivity are demanded for people in the recent century as they enable people to learn, live, and work in the new era.

As 21 st century skills become prioritized in most countries, education personnel need to take the burden to contribute the skills for learners. The 21 st century skills are proposed into classes through policies, learning management, and lesson plans. However, teaching in the $21^{\text {st }}$ century needs careful consideration of both learner, teacher, and policy aspects. Rotherham and Willinghan (2009) purposed that the skills should be added into classes in an integrating manner. It is not appropriate to directly create a subject that teaches 21 st century skills as the adaptive natures of the skills make it too broad for learners who have specific needs. Moreover, teacher training could be crucial in developing 21 st century skills as they should be able to apply appropriate instruction to their classes. In addition, 21 st century skills need a specific assessment to ensure that learners are ready to use them in education and life. Craig (2012) suggested that all stakeholders in an educational context need to corporate to apply strategies, activities, and tools in instructing 21 st century skills. Teachers, students, parents, local businesses, and local leaders are demanded to adopt a vision of 21 st century learning.

The importance of the 21 st century skills and the complication in instructing the skills drive scholars to consider an effective method that could help learners acquire the skills and encourage educational stakeholders' participation as it illustrates how learners could apply the skills in real uses. In this case, the professional learning community (PLC) is derived with the idea to drive out the cooperation of stakeholders such as school administrators, teachers, students, and parents to create a learning community that aims for learners' learning achievement (Boyer, 1995). According to the author, PLC is an effective method in education 
management as it encourages school administrators and teachers in branches of sciences to work as a corporation to assist and reflect each other work to bring the ultimate goal of learning and teaching that is students' success.

In Thailand, 21st century skills are also considered essential skills for learners. According to the Ministry of Education (2018), schools and educational institutions are expected to develop students' $21^{\text {st }}$ century skills under the 3 Rs 8 Cs plan. In detail, students are required to have reading, writing, and arithmetic skills (3Rs). Moreover, critical thinking and problem solving, creativity and innovation, cross-cultural understanding, collaboration, teamwork, and leadership, communications, information and media literacy, computing and ICT literacy, career and learning skills, and compassion (8cs) are also considered important. Developing students' 21 st century skills is not an easy task as the expectation from policymakers is demanding, and some skills are difficult to acquire in a certain context. Consequently, an effective method that could solve problems in instructing the skills should be implemented in the area.

With these rationales, the current study aims to investigate teacher perceptions toward the use of the professional learning community (PLC) implemented in the district of Lam Plai Mat to develop learners' 21 st century skills. Teachers' perception of the method should review the advantages and disadvantages of PLC in developing 21st century skills in the Thai context. Moreover, the data gained from the current study could be a guide to the possibility of implementing PCL to develop learners' skills in a similar context to Thailand. The sole purpose of the study is to study teacher perceptions of the professional learning community (PLC) in developing the 21 st century skills of students in Thailand.

\subsection{The Framework of 21st Century Learning}

The $21^{\text {st }}$ century arrives with new sets of knowledge and skills that change the lives of people around the globe. Therefore, learning these skills needs specific consideration as it concerns how learners could complete in academic and job market. According to the P21 Partnership for 21st Century Skills (2009), schools should maintain core subjects like language, arts, mathematics, economics, etc. with the awareness of 21 st century interdisciplinary themes such as global awareness, financial, economic, business, and entrepreneurial literacy, civic literacy, health literacy, and environmental literacy. In terms of skills and instruction, learning and innovation skills, information, media and technology skills, and life and career skills are prioritized. In detail, learners in the $21^{\text {st }}$ century need to be creative and innovative as people in the new era always seek new things to be impressed. Critical thinking and problems solving are important when the students face complicated difficulties in the current situation. Communicative and collaborative skills are also needed to connect people in the $21^{\text {st }}$ century. In terms of technology-related skills, learners need both technical skills for work and communication. They also need media literacy skills to encounter an unlimited flow of information in the era of advanced technology. Lastly, in life and career skills, learners need to learn to be adaptive and self-directed in work. They should have cross-cultural skills as they are expected to work with people from different cultures, traditions, and political points of view. Leadership and responsibility are also important as they could maintain work 
effectiveness and productivity. The framework of 21 st century learning could be seen in Figure 1.

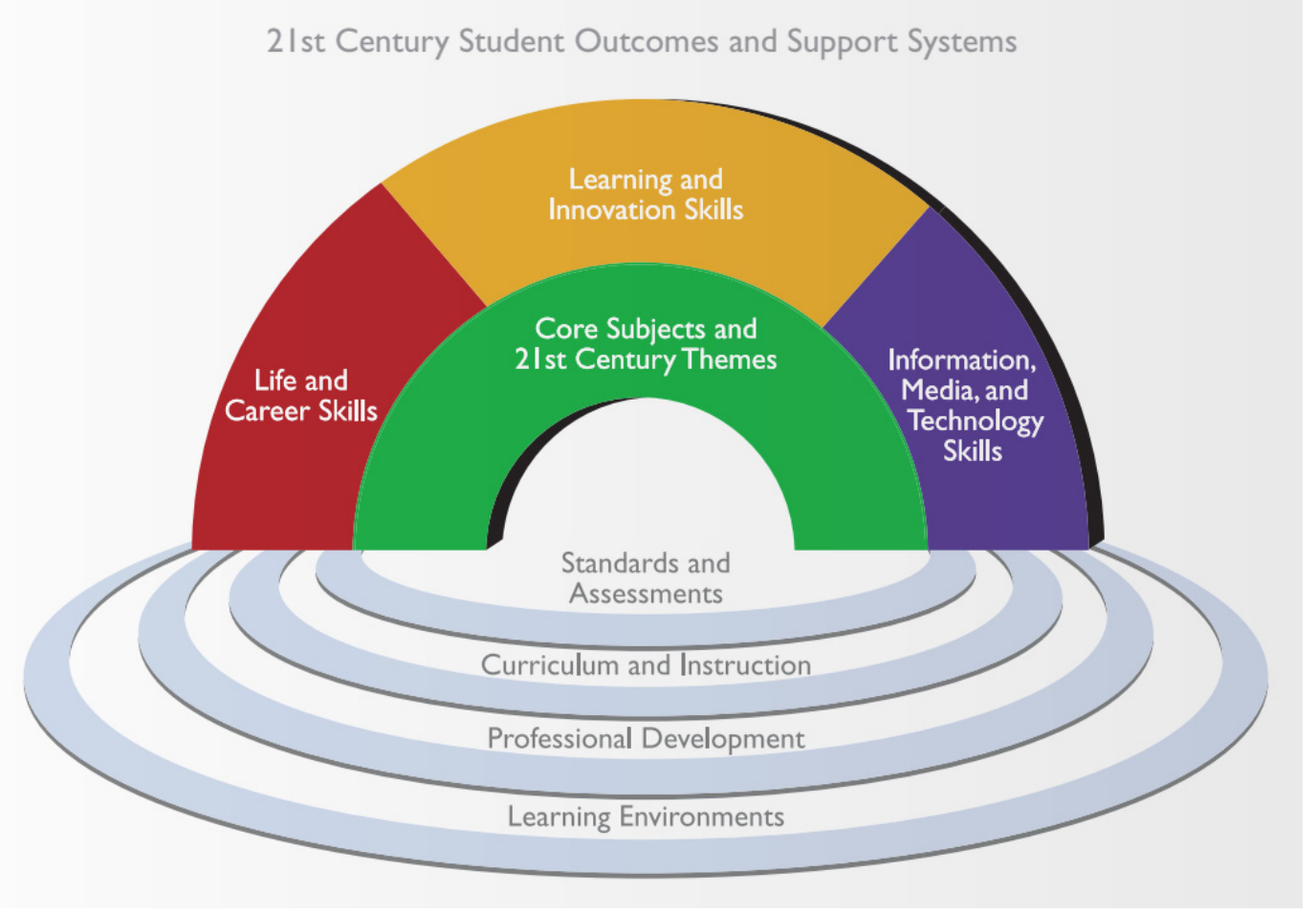

Figure 1. P21 $21^{\text {st }}$ century learning framework

\subsection{The Framework of $21^{\text {st }}$ Century Skill Instruction in Thailand}

In Thailand, $21^{\text {st }}$ century skills are included in the national education plan (Ministry of Education, 2018). Similar to the global trend of $21^{\text {st }}$ century skills, Thailand also emphasizes academic, technology, and life skills as important skills that could lead students in the country to a proper future in the new era. At this point, the concept of 3Rs8Cs is derived to illustrate the expected outcomes of $21^{\text {st }}$ century skill instruction. In detail, the first $3 R$ s are from reading, writing, and arithmetic abilities. The students are expected to have the ability to read and write effectively in their L1. Computation is also expected to help learners cope with problems encountered in life. These three skills are core abilities that could contribute to a decent academic future. In addition, 8Cs including critical thinking and problem solving, creativity and innovation, cross-cultural understanding, collaboration, teamwork, and leadership, communications, information and media literacy, computing and ICT literacy, career and learning skills, and compassion are also demanded as they are life skills that could be beneficial in the $21^{\text {st }}$ century. In detail, life and career need critical thinking and creativity to solve the unpredictability of challenges found in the $21^{\text {st }}$ century. Leadership, cross-cultural communication, and teamwork are important skills in working as a collaborative organization. Technology and ICT skills in terms of both knowledge and literacy could help learners to use information technology effectively. Lastly, learners need understanding and compassion for people from different cultures, traditions, and political points of view to live 
peacefully in the $21^{\text {st }}$ century. It could be noted that the $21^{\text {st }}$ century skills expected by the government indicate an interdisciplinary manner of instructing. The skills cover humanities, social sciences, and sciences as they are demanded to be used in a complicated and informative era of the $21^{\text {st }}$ century. Therefore, the collaboration of personnel in various fields might benefit student development of the skills.

\subsection{Professional Learning Community (PLC)}

As $21^{\text {st }}$ century skills are various and suitable for collaborative instruction from teachers from fields of study, the professional learning community (PLC) could be implemented to solve problems in the context. According to DuFour, DuFour, and Eaker (2008) could be defined as the collaboration of teaching staff and administrators with a specific goal such as enhancing teaching and learning quality and conducting a research project. Similarly, Barth (2006) suggested that PLC is learning management that allows teachers and school administrators to collaboratively share ideas and practices for the sake of teaching, learning, and students' achievement. Boyer (1995) noted that it is beneficial to bring community to school to support the learning environment. The stakeholders of PLC vary from school administrators, teachers, students, and the local community. Toole and Louis (2002) also suggested that the benefits of PLC rely on opportunities to collaborate between teachers. Reflection from teachers in branches of the field could lead the professional learning community to reach its goals. At this point, the collaboration of staff from disciplinaries with an aim to develop learning achievement could be an advantage of PLC in developing learners' $21^{\text {st }}$ century skills.

Since the method could be considered an alternative school administration that could both solve problems in the learning context and bring about unity to the community scholars have presented the model that helps in implementing the principles of professional learning community into real practice (e.g., DuFour, 2004; Hord, 1997; Senge, 1990). One of the famous principles is presented in Hord (1997) who presented 5 dimensions of the professional learning community (PLC) including shared vision and mission, leadership sharing and supportive leadership, collective learning and learning application, personal practice sharing, and organization support. The model has been recognized by various studies in the area (Verbiest, 2011; Wilson, 2016). The detail of Hord's professional learning community (1997) could be seen below. 


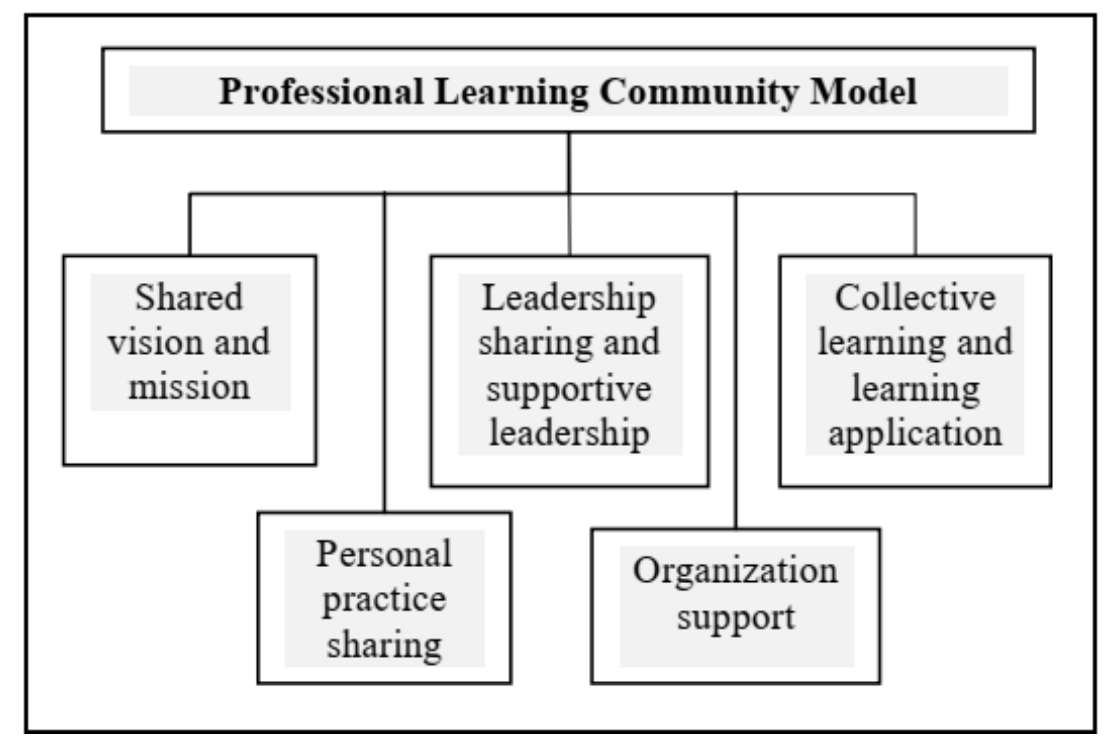

Figure 2. Hord's professional learning community (1997)

In detail, a professional learning community could be formed with a shared vision and mission among stakeholders of a learning context. All parties should be collaborated with the same goal - to develop students' learning achievement in a certain aspect. It could also be noted that when school leaders and teachers share their roles and responsibilities in a school, the good impacts of PLC (in terms of leadership) can be evident. The leadership of school administrators, heads of departments, and heads of teaching groups could also bring about effective sharing of authority which could lead to success in driving school vision. Furthermore, a collective learning process among the school community is needed in developing PLC. Continuous and collective learning among teachers and administrators should be supported in the processes of PLC development. In terms of personal practice sharing, teachers should always collaboratively learn and develop themselves with the support of their colleagues. A meaningful and insightful learning environment between teachers where feedback can be fairly shared with an awareness of students' needs, interests, and skills as the goal of collaboration should be formed. Lastly, organization support - interpersonal relationship and school structure could be crucial in developing PLC. As the method relies on co-working between staff, the fundamental element that could support a collaborative organization is the camaraderie among teaching staff. Schools should form a working structure that supports personnel relationships. The professional working environment where a systematic working structure is formed could support the development of PLC.

\subsection{Previous Studies}

As PLC is beneficial in education, scholars have studied the method in terms of both teacher development and student $21^{\text {st }}$ century learning. As the method focuses on using collaboration and idea-sharing among teaching staff, the benefits of PLC occur in teaching development (e.g., Buaklamtanakit, Kunagornpitak, \& Amatariyakul, 2019; Verbiest, 2011; Wilson, 2016; Choowong \&Worapun, 2021). For example, Verbiest (2011), studied the implementation of a 
professional learning community in 4 elementary schools in the Netherlands. The result of the project lasting 2.5 years indicates that PLC contributed to professional development, interdependence, innovative agenda, professional culture, leadership, and interpersonal relationship among teachers in schools participating in the project. In terms of learner development, the method has also been found to be beneficial in improving students' $21^{\text {st }}$ century learning in various studies (e.g., Fung Tam, 2015; Chediak, Kunnari, Inforsato, \& Ammorim Jr., 2018; Dufour \& Dufour, 2010; Prenger, Poortman, \& Handelzalts, 2018; Sroinam, 2018; Worapun, 2021). For instance, Dufour and Dufour (2010) suggested that PLC could lead to success in $21^{\text {st }}$ century skill instruction as schools need to collaborate among teachers in various sciences to help study acquire these skills. Moreover, the results of a study in 2 schools involving 82 teachers and 800 students in Finland in Cheiak et al. (2018) suggested that student development in the $21^{\text {st }}$ century is an outcome of the implementation of the professional learning community. It could be noted that PLC is an alternative school management and learning management method that could contribute to professional teacher development and students' $21^{\text {st }}$ century skills. The current study employed PLC in school management, and the perception of teachers who participate in the project in terms of its effects on students' $21^{\text {st }}$ century skills are studied under the research question of "What is teachers' perception of the professional learning community (PLC) in developing 21st century skills of students in Thailand?".

\section{Method}

\subsection{Participants}

The participants were 1154 teachers from 376 schools in 17 provinces in Thailand. The participants were selected purposively. The schools participating in the study were both at primary and secondary levels. All schools are assigned to implement a professional learning community to promote students' $21^{\text {st }}$ century skills. All participants were treated anonymously.

\subsection{Instruments}

The instruments were a professional learning community activity among teaching staff in the school and a questionnaire for teachers' perception of the method. School administrators and teachers were assigned to participate in a PLC group of discussion 2 times a week with an aim to develop practices in teaching and learning and students' learning achievement including $21^{\text {st }}$ century skills. All teaching staff needs to participate to present their teaching method, reflect problems, give and receive feedback. The possibility to integrate $21^{\text {st }}$ century skills in classes was discussed with the expertise of teachers from various fields of education. The discussion session was divided into grade level, grade range level, and school level to present a broader picture of the progress. The activity was proved to be appropriate by experts before being implemented into real practice $(\bar{x}=4.65$, S.D. $=0.87)$. Meanwhile, $a$ questionnaire was developed to study teacher perception of PLC in developing students' $21^{\text {st }}$ century skills. The questionnaire consisted of 16 question items under $821^{\text {st }}$ century skills including problem-solving and critical thinking skills, creative skills, communicative skills, career skills, life skills, discipline, honesty, and public mind. The Item objective congruences 
(IOC) of the questionnaire were found between $0.67-1.00$ rated by three experts.

\subsection{Data Collection}

The PLC activity took an academic year to complete. The questionnaire was used before the treatment to investigate the participants' perceptions of their students' $21^{\text {st }}$ century skills and used again after the project to investigate the participants' perceptions after taking part in the PLC.

\subsection{Data Analysis}

The data were analyzed using percentages, mean scores, and standard deviation.

\section{Results}

The result of the study shows teacher perceptions of students' $21^{\text {st }}$ century skills before and after professional learning community activities. The detail of each students' skills could be seen below. 
Table 1 . Teacher perceptions of students' $21^{\text {st }}$ century skills before and after professional learning community activities

\begin{tabular}{|c|c|c|c|}
\hline \multirow{2}{*}{ Aspects } & \multicolumn{2}{|c|}{ Processes } & \multirow{2}{*}{$\begin{array}{l}\text { Percentage } \\
\text { of change }\end{array}$} \\
\hline & Before PLC & After PLC & \\
\hline \multicolumn{4}{|l|}{ 1. Skills } \\
\hline 1.1 Problem-Solving and Critical Thinking Skills & 2.60 & 3.93 & 48.18 \\
\hline $\begin{array}{l}\text { Students can analyze role-play situations and make decisions } \\
\text { that connect to real life. }\end{array}$ & 2.58 & 3.95 & 51.15 \\
\hline $\begin{array}{l}\text { Students can select appropriate and relevant solutions to } \\
\text { problems. }\end{array}$ & 2.62 & 3.92 & 53.10 \\
\hline 1.2 Creative Skills & 2.51 & 3.91 & 49.62 \\
\hline Students can flexibly and variously think. & 2.63 & 4.04 & 55.78 \\
\hline Students can think of new processes and earn acceptance. & 2.39 & 3.78 & 53.61 \\
\hline 1.3 Communicative Skills & 2.79 & 4.08 & 58.16 \\
\hline $\begin{array}{l}\text { Students can effectively use both verbal and written language } \\
\text { in communication. }\end{array}$ & 2.80 & 4.15 & 46.24 \\
\hline Students can choose appropriate technology in communication. & 2.79 & 4.01 & 48.21 \\
\hline 1.4 Career Skills & 2.81 & 4.06 & 43.73 \\
\hline Students have knowledge of future careers. & 2.79 & 4.12 & 44.48 \\
\hline Students can apply knowledge in their careers. & 2.84 & 4.01 & 47.67 \\
\hline 1.5 Life Skills & 3.02 & 4.31 & 42.72 \\
\hline Students have progressive and positive thinking. & 2.97 & 4.28 & 44.11 \\
\hline Students can adapt to work with others. & 3.07 & 4.35 & 41.69 \\
\hline \multicolumn{4}{|l|}{ 2. Morality } \\
\hline 2.1 Discipline & 3.07 & 4.32 & 35.74 \\
\hline Students follow family, school, and society regulations. & 3.07 & 4.29 & 39.74 \\
\hline Students are punctual in both learning and activities. & 3.08 & 4.36 & 41.56 \\
\hline 2.2 Honesty & 3.21 & 4.27 & 33.02 \\
\hline Students are honest with others and themselves. & 3.18 & 4.27 & 34.28 \\
\hline Students are honest to society and culture. & 3.24 & 4.28 & 32.10 \\
\hline 2.3 Public Mind & 3.31 & 4.40 & 32.93 \\
\hline Students offer help without asking something in return. & 3.30 & 4.39 & 33.03 \\
\hline $\begin{array}{l}\text { Students willingly participate in useful activities for family, } \\
\text { school, and society. }\end{array}$ & 3.32 & 4.41 & 32.83 \\
\hline Average & 3.15 & 4.30 & 36.51 \\
\hline
\end{tabular}


The results of the study indicate that the average perception of teachers on students' $21^{\text {st }}$ century skills after the PLC was at a high level and $(\overline{\mathrm{x}}=4.30)$ higher than before the PLC which was at an average level $(\bar{x}=3.15)$. In detail, teachers reported that the students in their classes could better analyze role-play situations and make decisions that connect to real-life $(\overline{\mathrm{x}}=3.95)$, and select appropriate and relevant solutions to problems $(\overline{\mathrm{x}}=3.92)$. In terms of creative skills, it was reported that the students showed better flexibility and variety of thinking $(\bar{x}=4.04)$. Moreover, they are perceived to be innovative in thinking $(\bar{x}=3.78)$. In the communicative skills, teachers reported a high level of students' ability in using verbal and written communication $(\bar{x}=4.15)$. They were also reported to choose appropriate technology in communication $(\bar{x}=4.01)$. In terms of career skills, the students were reported to conceptualize future careers $(\overline{\mathrm{x}}=4.12)$ and apply knowledge into career development $(\overline{\mathrm{x}}=$ 4.01). In addition, life skills in terms of progressive and positive thinking $(\overline{\mathrm{x}}=4.28)$ and adaptability in work $(\overline{\mathrm{x}}=4.25)$ were reported. Regarding the moral aspect, students' disciplines were reported to be improved in terms of both respect to the family, school, and society regulation $(\bar{x}=4.29)$, and punctuality $(\bar{x}=4.36)$. In terms of honesty, the students were reported to be honest to others and themselves $(\bar{x}=4.27)$ and honest to society and culture $(\bar{x}=4.28)$. In terms of the public mind, students were reported to offer help without asking for something in return $(\overline{\mathrm{x}}=4.39)$ and willingly participate in useful activities for the family, school, and society $(\bar{x}=4.41)$. It could be interpreted that the professional learning community (PLC) as the managerial method of school administration could lead to positive perceptions of teachers in developing students' $21^{\text {st }}$ century skills.

\section{Discussions}

The results of the study revealed positive perceptions of teachers on the use of the professional learning community in developing students' $21^{\text {st }}$ skills. The result could lead to the issues discussed below.

It could be noted that teachers participating in the project believed that PLC activities could lead to the improvement of students' $21^{\text {st }}$ century skills in terms of problem-solving and critical thinking skills, creative skills, communicative skills, career skills, and life skills. The results of the study are consistent with Cheiak et al. (2018) who also found the benefits of professional learning community in improving learners' $21^{\text {st }}$ century skills. In this case, $21^{\text {st }}$ century skills are complicated and need multi-disciplinary fields to develop (Craig, 2012). Moreover, $21^{\text {st }}$ century skills in the study need a variety of instruction in humanities, social sciences, and sciences to contribute to learner achievement. For example, it takes scientific knowledge to be able to use technology in communication and it also humanities knowledge to communicate effectively. Therefore, the PLC takes part in student development as it allows teachers from different departments to share ideas, reflect on problems, and seek the most appropriate way in developing students (Toole \& Louis, 2002). In the current study, teaching staff and school administrators set a common goal to improve students' $21^{\text {st }}$ century skills. They took part in PLC meetings twice a week for an academic year, and it results in the development of students. This could confirm the benefits of PCL in developing human resources in the new era. 
Morality is also needed in $21^{\text {st }}$ century skills as it supports other skills. Compassion and understanding are the keys to success in cross-cultural communication. Developing students to have discipline, honesty, and public mind, therefore; help them to live as a member of $21^{\text {st }}$ world society. The result of the study indicates teachers' positive perception in using professional learning community in implanting students' morality that is necessary for $21^{\text {st }}$ century skills. It confirms the benefit of the PLC in implanting learners' social and life skills (Cheiak et al., 2018). According to P21 21 ${ }^{\text {st }}$ century learning framework (2007), even though morality is not mentioned in the framework, it contributes to the core skills of the framework. To illustrate, learners need to be honest and disciplined in collaborative working which is a skill in the framework. Moreover, a service mind is also required in the Thai government 3Rs8Cs model of $21^{\text {st }}$ century learning (Ministry of Education, 2019). Consequently, the collaboration among teaching staff and school administration in PLC activities could improve students' $21^{\text {st }}$ century skills through morality instruction that is a result of shared ideas and the discussion of the group.

Overall, it could be claimed that in teachers' opinion, PLC was capable of developing student skills and morality of $21^{\text {st }}$ century. The collaboration of stakeholders in a learning institution could build up confidence in developing such complicated skills in $21^{\text {st }}$ century. According to Hord (1997), the success of PLC relies on a shared vision and mission in the organization. In the current study, the vision to develop students' $21^{\text {st }}$ skills was shared among teaching staff and school administration. They also assign responsibility as leaders in class, grade, and school level are assigned to drive the project. Hord's model also suggests personal practice sharing. In each meeting, the group leader encouraged idea sharing, and it results in practices that led to the improvement of students' $21^{\text {st }}$ century skills.

\section{Conclusion}

The core investigation of the current study was to investigate teacher perceptions toward PLC in developing students' $21^{\text {st }}$ century skills in Thailand. The data collection took part in an upscale sample size of 1154 teachers from 376 schools in 17 provinces across the country. The results of the study could be summarized to indicate the positive perception of teachers in using the professional learning community as a school managerial method in developing skills and morality of $21^{\text {st }}$ century. It could also be concluded that collaboration and idea-sharing among teaching staff and administrators were the keys to success. Therefore, the results of the study could be implicated in school management that aims to develop students' $21^{\text {st }}$ century skills.

However, the study still bears limitations that could be improved in further studies. The data collection consists only of a quantitative method. Further studies could provide qualitative aspects to make teacher perception of PLC more comprehensible. Moreover, the current study was only a survey of teacher perception. Including valid tests of students' $21^{\text {st }}$ century abilities could more precisely illustrate the effects of PLC on learners' $21^{\text {st }}$ century skills. Furthermore, further studies could also investigate teacher perception of teaching methods gained from the processes of PLC. Students' perception of the teaching method of PLC could also be an interesting research topic. 


\section{Acknowledgements}

The study could not be completed without the support of the Equitable Education Fund, Education Foundation, and Mahasarakham University, Thailand.

\section{References}

Baker, F. M., \& Lightfoot, O. B. (1993). Psychiatric care of ethnic elders. In A. C. Gaw (Ed.), Culture, ethnicity, and mental illness (pp. 517-552). Washington, DC: American Psychiatric Press.

Barth, R. (2006). Improving relationships within the schoolhouse. Educational Leadership, 63(6), 8-13.

Boyer, E. L. (1995). The basic school: A community for learning (1st ed.). San Francisco: Jossey-Bass.

Buaklamtanakit, S., Kunagornpitak, P., \& Amatariyakul, W. (2019). The 21st century teacher skills affecting professional learning communities of teachers in schools for the deaf under special education bureau. Ubon Ratchathani Journal of Research and Evaluation, 8(1), 50-59.

Chediak, S., Kunnari, I., Inforsato, E., \& Ammorim Jr., J. (2018). Professional learning communities as a leadership strategy in the $21^{\text {st }}$ century school management. Revista Ibero-Americana de Estudos em Educação, 13, 304-323. https://doi.org/10.21723/riaee. nesp1.v13.2018.11408

Choowong, K., \& Worapun, W. (2021). The Development of Scientific Reasoning Ability on Concept of Light and Image of Grade 9 Students by Using Inquiry-Based Learning 5E with Prediction Observation and Explanation Strategy. Journal of Education and Learning, 10(5), 152-159. https://doi.org/10.5539/jel.v10n5p152

Craig, J. (2012). Six steps for implementing 21st century skills. New York, USA: Onondaga-Cortland-Madison BOCES.

Dede, C. (2009). Comparing frameworks for 21st century skills. Retrieved October 6, 2021, from http://watertown.k12.ma.us/dept/ed_tech/research/pdf/ChrisDede.pdf

DuFour, R. (2004). What Is a "Professional Learning Community"? Educational Leadership, 61, 6-11.

DuFour, R., \& DuFour, R. (2010). The role of professional learning communities in advancing 21 st century skills. In J. Bellanca \& R. Brandt (Eds.), 21st century skills: Rethinking how students learn (pp. 77-95). Bloomington, IN: Solution Tree Press.

DuFour, R., DuFour, R., \& Eaker, R. (2008). Revisiting professional learning communities at work: New insights for improving schools. Bloomington, IN: Solution Tree. 
Fung Tam, A. C. (2015). The role of a professional learning communityin teacher change: A perspective from beliefs and practices. Teachers and Teaching, 21(1), 22-43. https://doi.org/ $10.1080 / 13540602.2014 .928122$

Hord, S. M. (1997). Professional learning communities: Communities of continuous inquiry andimprovement. Austin, TX: Southwest Educational Development Laboratory.

Klafehn, J. (2017). Cross-cultural competence as a 21st century skill. In J. Burrus, M. Mattern, B. Naemi, \& R. Robert (Eds.), Building better students: preparation for the workforce (pp.73-110). Oxford: Oxford University Press. https://doi.org/10.1093/acprof:oso/ 9780199373222.003 .0004

P21 Partnership for $21^{\text {st }}$ Century Skills. (2009). Framework for $21^{\text {st }}$ century learning. Retrieved October 21, 2021, from https://www.teacherrambo.com/file.php/1/21st_century_ skills.pdf

Prenger, R., Poortman, C., \& Handelzalts, A. (2018). The effects of networked professional learning communities. Journal of Teacher Education, 70(5), 751-752. https://doi.org/10.1177/ 0022487117753574

Rotherham, A., \& Willingham, D. (2009). 21st century skills: The challenges ahead. Teaching for the 21st Century, 67(1), 16-21.

Senge, P. M. (1990). The fifth discipline: The art and practice of the learning organization. Doubleday, New York: MCB UP Ltd.

Sroinam, S. (2018). The Characteristics of Professional Learning Community of Primary Schools in Udon Thani Province. Journal of Education \& Social Policy, 5(2), 142-147. https://doi.org/10.30845/jesp.v5n2a15

The Ministry of Education. (2018). National education plan 2018-2033. Bangkok, Thailand: Office of Education Council.

Toole, J. C., \& Louis, K. S. (2002). The role of professional learning communities in international education. In K. Leithwood \& P. Hallinger (Eds.), Second international handbook of educational leadership and administration. Dordrecht: Kluwer. https://doi.org/ 10.1007/978-94-010-0375-9_10

Verbiest, E. (2011). Developing professional learning communities. Paper presented at the American Educational Research Association Conference, New Orleans, LA.

Whorton, R., Casillas, A., Oswald, S., \& Shaw, A. (2017). Critical skills for the 21st century workforce. In J. Burrus, M. Mattern, B. Naemi, \& R. Robert (Eds.), Building better students: Preparation for the workforce (pp. 47-72). Oxford: Oxford University Press. https://doi.org /10.1093/acprof:oso/9780199373222.003.0003

Wilson, A. (2016). From professional practice to practical leader: Teacher leadership in professional learning communities. International Journal of Teacher Leadership, 7(2), 45-62.

Worapun, W. (2021). The development of research-based learning management in the 


\section{Macrothink

curriculum design and development course for teacher students. Journal of Education and Learning, 10(6), 62-67. https://doi.org/10.5539/jel.v10n6p62

\section{Copyright Disclaimer}

Copyright for this article is retained by the author(s), with first publication rights granted to the journal.

This is an open-access article distributed under the terms and conditions of the Creative Commons Attribution license (http://creativecommons.org/licenses/by/3.0/). 